\title{
Contribution of Certification and School Climate Allowances to The Motivation of Teacher Work in the Middle School District of Kinali, West Pasaman Regency
}

\author{
Lusiana ${ }^{1, a}$ Kasman Rukun ${ }^{1, b}$ Yahya ${ }^{1, c}$ \\ 1Department of Administration Education, State University of Padang, Padang, Indonesia \\ a nlusiae@gmail.com; b kasmanrukun@gmail.com; c yahya@yahoo.com \\ ${ }^{*}$ Corresponding Author
}

How to Cite : Lusiana, L., Rukun, K., Yahya, Y. (2019). Contribution of Certification and School Climate Allowances to The Motivation of Teacher Work in the Middle School District of Kinali, West Pasaman Regency. International Journal for Educational and Vocational Studies, 1 (5), 509-513

\section{ARTICLE HISTORY}

Received: 19 June 2019

Revised: 10 July 2019

Accepted: 21 August 2019

\section{KEYWORDS}

Certification Allowances; School Climate;

Work Motivation;

\begin{abstract}
The objectives of this study are (1) Contribution of certification to teacher work motivation, (2) Contribution of the school climate to teacher work motivation, (3) Contribution of certification allowances and school climate together to work motivation. This type of research is quantitative correlational in nature, the population in this study were all junior high school teachers in Kinali sub-district with the status of civil servants with a population of 107 people, a sample of 30 people taken using the startified proportional random sampling technique. Data collection techniques using questionnaires, data analysis techniques (1) description of data, (2) testing requirements analysis and (3) testing hypotheses. The results of the study prove that (1) There is a contribution of certification to work motivation because certification contributes $25.6 \%$ to the teacher's work motivation (2) the school climate contributes $28.3 \%$ to the teacher's work motivation (3) certification and the school climate together contribute $37.5 \%$ to the motivation of the teacher's work. Suggestions that can be put forward based on the findings to improve the work motivation of the teacher are expected that the principal can provide certification allowances to teachers who meet the requirements. To increase the work motivation of teachers, it is necessary to fix the low school climate, the Supervisors to provide a school climate of cooperation with teachers in accordance with technological developments. The education office's policy in terms of managing learning in schools should aim at increasing certification allowances.
\end{abstract}

This is an open access article under the CC-BY-SA license.

\section{INTRODUCTION}

Technological developments in the current era of globalization have brought changes that affect almost all aspects of human life and various problems that arise can only be solved by mastering science and technology itself. Therefore, increasing resources becomes an unavoidable reality and must be implemented in a planned manner, directed, intensive, effective, and efficient. One of the means to improve the quality of human resources is through education. According to Basuki W (2005) education has become a necessity to determine the direction for the future of humans, even the future of one nation. Whereas Quisumbung (2003) in Kunandar (2010) states that education has a major role in personal and social development, influencing individual and social change, peace, freedom and justice. Without going through a good educational process it will be difficult for someone to adjust to the development and progress of the times. Therefore education that is able to answer the chal- lenges of life in modern times is absolutely necessary. Providing quality education is something that must be realized by various efforts in a consistent and sustainable manner.

Junior High School (SMP) as one of the providers of secondary education that prepares students. For this reason, teachers are required to have the ability, knowledge, skills, education, and experience so that they are able to carry out the learning process properly. In connection with the important role of teachers in organizing learning, Moedjirto (2002.2) states that teachers are the spearhead of school activities, because they deal directly with students. Student success is very closely related to the teacher's performance in managing teaching and learning in front of the class. According to M, Marland (1987), the success or failure of education depends on the teacher and teaching, as well as the reciprocal relationship between the teacher and teaching 
in the classroom. Furthermore Brand (1993) in Mulyasa (2007: 9), states that almost all education reform efforts all depend on teachers. Without mastery of the material and learning strategies, as well as motivation motivation to learn seriously to their students, all efforts to improve the quality of education will not get maximum results.

Based on the opinions above, no doubt how important the role of teachers in improving the quality of education. Starting from this thought, the improvement in the ability of teachers to carry out their tasks is an aspect that must be the initial foothold in efforts to improve the quality of learning that will ultimately improve the quality of education itself. Correspondingly, Sagala (2009: 14) states it is necessary to seriously consider how to give high priority to teachers, so that they can get the opportunity to always improve their ability to carry out their tasks according to their ability to carry out their duties as teachers. Teachers must be given the confidence to carry out their duties to carry out good teaching and learning processes. Teachers need to be given encouragement and a conducive atmosphere to determine alternative methods and ways to develop learning processes that are in accordance with the times.The implementation of teacher certification began in 2007 after the issuance of Minister of Education Regulation No. 18 of 2007 concerning Certification for Teachers in Occupation This year is the third year of the implementation of teacher certification in office. The foundation used as the basis for organizing teacher certification in 2009 is Government Regulation No. 74 of 2008 concerning Teachers. Therefore, there are some fundamental changes in the process of determining teacher certification participants in 2009.

The target number of teacher certification participants each year is determined by the Government in this case the Ministry of National Education. The stages of implementing teacher certification begin with the establishment of a committee for implementing teacher certification at the provincial and district/city level, granting quotas to provincial and district/city education offices, and determining participants by provincial and district/city education offices. In order for all agencies, namely provincial and district/city education offices, LPMP and elements related to the implementation of teacher certification to have the same understanding of the criteria and the process of determining teacher certification participants, it is necessary to formulate Guidelines for Determination of Teacher Certification Participants in Position.

Professional lecturers are inspirational teachers in all ways so as to provide an example for creative students to develop students in an effort to reach their potential optimally and be able to present an atmosphere of achievement for students (E.Erpidawati \& Susanti, 2019). Through initial observation and conversation with the principal and found in a number of conditions or phenomena associated with implementing the duties of the teacher. The conditions are as follows: (1) some teachers still have not implemented syllabus development and tend to only use existing syllabi or made by other schools , (2) there are still teachers who carry out learning without guidance (RPP), even though making lesson plans is one of the main tasks of teachers before carrying out learning, (3) some teachers like to leave the classroom when learning takes place and do other activities, (4) there are still many teachers who do not try to use media, improve methods and use varied learning strategies, thus making students less active and resulting in a monotonous learning atmosphere, (5) there are still teachers who do not master the material being taught or teach material that is in accordance with standard competencies students should leave in the task load, (6) there are still teachers who have not carried out objective and ongoing learning evaluations where most of the students' assignments or exam papers are left to pile up and are not examined, (7) extra-curricular activities have not been carried out continuously, but are only carried out if there are certain moments.

Based on the description of the observations and survey above, it can be seen that there are many problems related to the implementation of the teacher's duties as the main actor in the education process at school. This problem if not immediately addressed and looked for a solution will certainly have a negative impact on the learning process and will ultimately affect the quality of education. Therefore, the author feels the need to further examine the problems regarding the work motivation of teachers in Kinali District Junior High School.

\section{METHODS}

This study uses a quantitative method with correlational type of research to see the contribution will reveal the contribution of education and training (training) and school climate to teacher work motivation. The population in this study were all state junior high school teachers in Kinali Subdistrict who were civil servants in the 2014/2015 school year with a total of 107 people. The sample of this study was taken using a statfied proportional random sampling technique totaling 30 people. Data collection is done by meeting the research subjects directly. The data analysis technique of this research will be processed using correlation and regression techniques with the help of SPSS version 20 .

\section{RESULTS AND DISCUSSION}

The Effect of Certification Allowances on Work Motivation

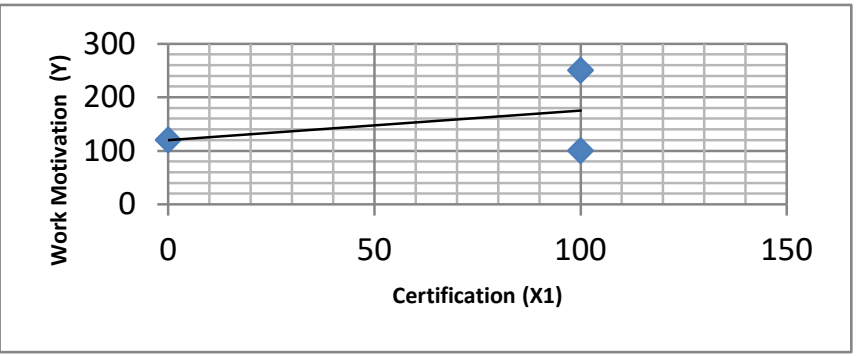

Figure 1. Work Motivation on certification 
The results of the analysis of the data of this study showed that the certification allowance contributed to teacher work motivation by $25.6 \%$. This means that teacher work motivation is interpreted through certification allowances. certification (X1) on work motivation (Y), whether predictive or not, a simple regression analysis is performed. From the analysis results obtained by the regression equation. Then persa $\hat{Y}$ $=95.749+0.702 \mathrm{X} 1$.

In the Law of the Republic of Indonesia Number 14 of 2005 concerning teachers and lecturers, it is stated that certification is the process of giving educator certificates to teachers and lecturers. According to Mulyasa (2007: 33), educator certificates are formal proof as professional staff, while teacher certification is a process of giving recognition that a person already has the competence to carry out education services in certain education units after passing the competency test held by the certification body.Teacher certification is a competency test process designed to express mastery of competencies that are designed to reveal the mastery of one's competence as a basis for giving educator certificates (Mulyasa, 2007: 33).

Effect of School climate on teacher work motivation

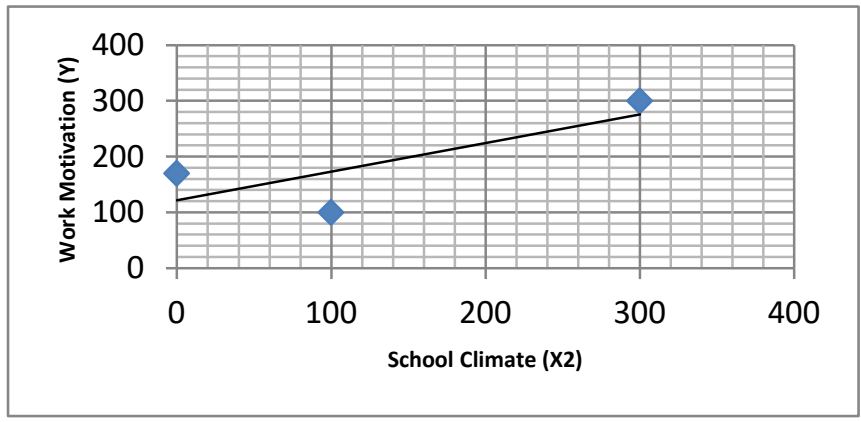

Figure 2. Work Motivation on school climate

The results of research that have been carried out that there is a contribution of the school climate to teacher work motivation of $28.3 \%$, the results of this study support the theory proposed by Moos in Hadiyanto (2008) the dimensions of school climate determinants, namely: 1) the relationship dimension, 2) dimensions of personal growth/development (personal growth development), 3) dimensions of change and improvement System (System maintenance and change). The opinion of Moos was added by Arter (1989) with one more dimension namely 4) the dimension of the physical environment (pshycal environment). School climate can increase teacher work motivation.School climate (X2) with work motivation (Y), whether the relationship is predictive or not, a simple regression analysis is performed. From the analysis results obtained by the regression equation $\hat{\mathrm{Y}}=93.296+$ $0.537 \mathrm{X} 2$.

Research conducted by Research conducted by Siahan (1991) with the title "Discipline of work, School Climate, and Its Relationship with Teacher's Work Motivation in Padang City High School". From the results of his research it was found that the school climate contributed
$31 \%$ to the work motivation of teachers.

According to Syaiful Sagala (2009: 30) teachers must take certification, because with certification a teacher will increase their ability and involvement in carrying out their duties as a teacher. The Law of 2005 Number 14 Teachers and Lecturers states that certification is part of improving teacher quality and improving their welfare. Masnur Muslich (2007: 7) said that with certification teachers are expected to become professional educators, namely competency as learning agents as evidenced by the ownership of an education certificate after passing the competency test. The influence of the certification allowance and the school climate together contribute to teacher work motivation.

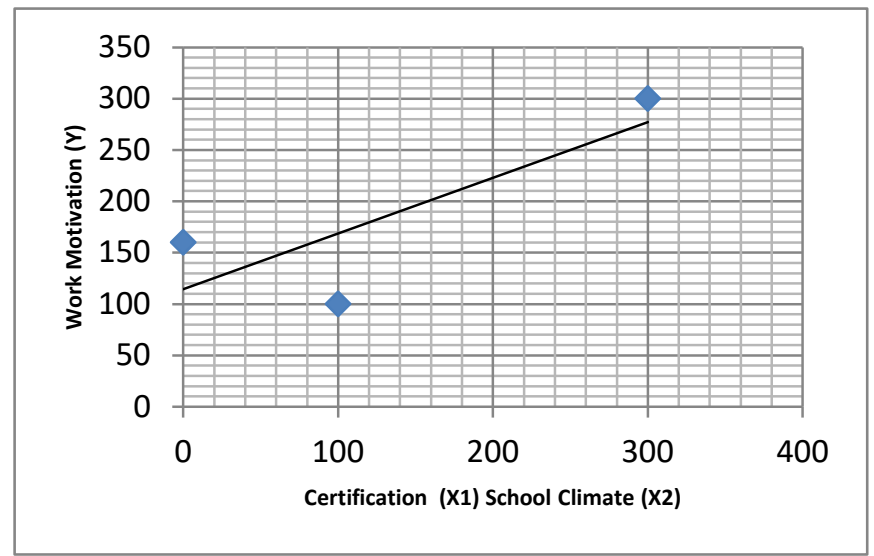

Figure 3. Work Motivation on Certification and school climate

The results showed that the certification allowance and school climate together contributed to the work motivation of teachers by $37.5 \%$. certification (X1) and school climate (X2) with work motivation (Y), whether the relationship is predictive or not, a multiple regression analysis is performed. The results of the analysis obtained a regression equation $\hat{\mathrm{Y}}=56.504+0.467 \mathrm{X} 1+0.378 \mathrm{X} 2$.

This is in line with the theory put forward by Wahjosumidjo (1988: 29) which says that the factors that influence work motivation are external factors and internal factors. External factors include: the leadership style of superiors, the environment, competencies, demands for organizational development and career coaching. While internal factors include work ability, morale, responsibility, a sense of togetherness in group life and achievement and work productivity The results of this study indicate that certification and school climate allowances contribute to teacher work motivation, to increase motivation, of course, teachers must provide certification support and school climate. If this can be improved, work motivation will also increase properly.

\section{CONCLUSION}

Based on the results of the analysis it can be concluded as follows: 1) the certification allowance for work motivation of Kinali District Junior High School 25.6\%, meaning that 
teacher work motivation can be interpreted through the certification allowance while descriptively that the certification allowance of Kinali District Junior High School teachers as a whole the indicators included enough categories. 2) School climate contributes to the work motivation of SMP Negeri Kinali District by $28.3 \%$, this means that work motivation is interpreted through the school climate, in this case the better the school climate the more work motivation of teachers will be. 3) Certification and school climate allowances together contribute to work motivation by $37.5 \%$. This explains that to increase good and ideal work motivation should be done through increasing certification allowances and creating a better school climate.

Efforts to Increase Certification Allowances So that work motivation can work well can be improved by providing certification allowances for teachers, or by providing competency development to teachers, and appreciation for teachers to have motivation in carrying out their duties, so that student learning outcomes for the better. The results of data analysis and hypothesis testing show that the certification allowance and school climate together or partially actually contributed to the work motivation of teachers at the Kinali District Junior High School. If the certification and school climate allowances are not improved it will affect work motivation and will impact on the quality of education.

Efforts to Improve School Climate With regard to the school climate which contributes to work motivation, it means that the school climate will be able to influence the work motivation of Neri Junior High School teachers in Kinali District. Efforts that can be done are by respecting each other at school, a sense of respecting at school can increase teacher work motivation where the teacher feels what he is doing at school is not in vain so that the work motivation of teachers in carrying out their tasks at school becomes better, the teacher will gained confidence in teaching for the better. Work motivation is an effort made and the results that can be achieved by teachers in creating a working atmosphere in schools to realize educational goals effectively and efficiently, productively, and accountably, therefore, teachers have a very important position in improving the quality of education in schools in order to run in accordance with the demands of society and the development of the needs of the times, especially the progress of science, technology.

The teacher is one component that occupies a central position and is very strategic in the education system the quality of education at the education unit level can be demonstrated by the phenomenon of schools that have advantages and are competitive. One indication of a school that has excellence and is competitive is the appearance of students' attitudes and behavior in accordance with applicable norms and an increase in student achievement, one of which can be seen from the percentage of graduation above the national standard (Titin Eka Ardiana, 2017).
The success of a teacher in teaching is determined by three main factors, 1) must have the ability to teach, which is an ability which is a combination of natural abilities that are: "awakened" through education and training, 2) must have and be able to use tools (devices and learning media) appropriate for teaching, 3) must have a high motivation or motivation and have an innovative attitude and personality. Other factors that affect the performance of teacher professionalism there are incentives, incentives are one of the factors driving or encouraging someone in carrying out their duties and responsibilities, but the phenomenon in get incentives that are not in line with what is expected and the provision of incentives to teachers should be given every month, but in reality the incentives are not timely (Erpidawati, 2017)

Based on the findings of this study, several suggestions were made as recommendations to various parties as follows: 1) To increase the work motivation of teachers, it is hoped that the school principal can provide certification allowances for teachers who have met the requirements. With the certification allowance received by the teacher, it can improve the welfare of the teacher's family. 2) To increase the work motivation of teachers, it is expected that the school climate which is classified as low is improved in terms of mutual respect for each other so that it can be further improved, so that teachers feel comfortable in school and carry out their tasks in the teaching process in the classroom to be better. 3) A good school climate is needed by the teacher where the teacher needs close relationships at school so that the school environment is considered a teacher as his own family so that the teacher prioritizes the interests of the school, respect each other and have good cooperation, a safe environment and a comfortable environment in carrying out the tasks at school In an organization mutual respect is necessary, so that disputes and misunderstandings with teachers occur, respecting one another is necessary because respecting each other is an individual trait that can accept co-workers. 3) The principal as the highest leader is expected to always try to increase motivation this can be done by guiding, directing and nurturing the teacher in carrying out tasks in school. 4) Supervisors, in order to provide a climate of cooperation to teachers in accordance with current technological developments and present and provide experience for teachers in developing lesson plans. 5) Education Service Policy in terms of organizing learning in schools should be related to increasing certification allowances. And policies that can increase work motivation. This can be done by making policies and rules clearer and more certain. 6) The results of this study are limited to the factors of certification allowance and school climate which can contribute to work motivation. While there are still other factors that affect work motivation. Therefore. It is expected that further researchers will conduct research relating to other variables that are thought to have contributed to work motivation. 


\section{REFERENCES}

Erpidawati, E., \& Susanti, E. (2019). Kontribusi Pengelolaan Manajemen Kelas Terhadap Hasil Belajar Mahasiswa Fakultas Kesehatan Dan Mipa Universitas Muhammadiyah Sumatera Barat. Jurnal Benefita: Ekonomi Pembangunan, Manajemen Bisnis Dan Akuntansi, 4(1), 70-77.

Erpidawati, Adri, R. F. (2017). Pengaruh Motivasi Kerja Dan Insentif Terhadap Kinerja Profesionalisme Guru SD Muhammadiyah Kota Padang. Menara Ilmu, 11(77).

Istriarini dan Sukanti (2012) Pengaruh Sertifikasi Guru dan Motivasi Kerja Guru Terhadap Kinerja Guru SMA Negeri 1 Sentolo Kabupaten Kulon Progo Tahun 2012. Jurnal Pendidikan Akuntansi Indonesia Forum Kajian Isu Terknin 1 (2012)

Kunandar. (2010). Guru Profesional.Jakarta: Rajawali Press.

Kusumi, J. S. (2019). Hubungan Budaya Sekolah Dan Komitmen Guru Dengan Motivasi Kerja Guru Di Sekolah Dasar Negeri Se-Kota Selatan Kota Gorontalo. Ideas: Jurnal Pendidikan, Sosial dan Budaya, 6(2), 157-172.

Majid, Samsidah. Headmasters' Transformati-onal Leadership and Their Relationship with Teachers' Job Satisfaction and Teachers' Commitments International Education Studies; Vol. 7, No. 13; 2014

Moedjiarto, (2002). Sekolah Unggul, Surabaya: Duta Graha Pustaka.

Mulyasa,E. (2007). Menjadi Guru Profesional. Bandung : PT. Remaja Rosdakarya.

Nana Sudjana. (2009). Penilaian Hasil Proses Belajar Mengajar. Bandung: PT Remaja Rosdakarya.

Nadarasa,Thusyanthini. The Inflence Of Principals' Leadership Styles On School Teachers' Job Satisfaction -Study Of Secondary School In Jaffna District. International Journal of Scientific and Research Publications, Volume 4, Issue 1, January 2014

Rusydi, Salman. (2011). Prinsip-Prinsip Manajemen Kelas. Yogyakarta: Diva Press.

Rahardjo, Sri. (2014). The Effect Of Competence, Leadership And Work Environment Towards Motivation And Its Impact On The Performance Of Teacher Of Elementary School In Surakarta City, Central Java, Indonesia.Vol. 3, No.6

Samino dan Saring Marsudi. (2012). Layanan Bimbingan Belajar. Kartasura: Fairuz Media

Samino. (2011). Manajemen Pendidikan Spirit Keislaman dan Keindonesiaan. Kartasura: Fairuz Media.

Sagala. S. (2006). Konsep dan Makna Pembelajaran. Bandung: Alfabeta

Sopia, Popi. (2010). Manajemen Belajar Berbasis Kebiasaan Siswa. Bogor: Ghalia Indonesia.
Terhadap Kinerja Guru Akuntansi SMK Di Kota Madiun.Jurnal Akuntansi Dan Pajak, Vol. 17, NO. 02, Januari 2017

Undang-Undang Republik Indonesia No. 20 Tahun 2003 pasal 15 tentang pendidikan

Wahjosumidjo, (2004). Kepemimpinan dan Motivasi, Jakarta: Ghalia Indonesia

Titin Eka Ardiana. (2017). Pengaruh Motivasi Kerja Guru 